${ }^{6}$ McKinney RM, Thacker L, Harris PP, et al. Four serogroups of legionnaires' disease bacteria defined by direct immunofluorescence. Ann Intern Med 1979;90:621-4.

${ }^{7}$ Fisher-Hoch S, Hudson MJ, Thompson MH. Identification of a clinical isolate as Legionella pneumophila by gas chromatography and mass spectometry of cellular fatty acids. Lancet 1979;ii:323-5.

${ }^{8}$ Nagington J, Wreghitt TG, Smith DJ. How many legionnaires ? Lancet 1979 ;ii:536-7.

9 McDade JE, Brenner DJ, Bozeman FM. Legionnaires' disease bacterium isolated in 1947. Ann Intern Med 1979;90:659-61.

${ }^{10}$ Cordes LG, Wilkinson HW, Gorman GW, Fikes BJ, Fraser DW. Atypical legionella-like organisms : fastidious water-associated bacteria pathogenic for man. Lancet $1979 ; \mathrm{ii}: 927-30$.

${ }^{11}$ Myerowitz RL, Pasculle AW, Dowling JN. Opportunistic lung infection due to "Pittsburgh pneumonia agent." New Engl f Med 1979;301:953-8.

12 Miller AC. Early clinical differentiation between legionnaires' disease and other sporadic pneumonias. Ann Intern Med 1979;90:526-8.

13 Macrae AD, Greaves PW, Platts P. Isolation of Legionella pneumophila from blood culture. $\mathrm{Br} \mathrm{Med} \mathcal{F} 1979 ; \mathrm{ii}: 1189-90$.

\section{Give sorrow words}

Everyone is afraid to talk about dying-doctors and nurses as well as patients and their relatives. This was the starting point of the recent conference "Death: The Last Taboo" held by the London Medical Group. Yet many patients prefer knowledge to uncertainty, ${ }^{12}$ and go through much unnecessary suffering because of the conspiracy of silence; they may even want to talk explicitly about death but feel it would be unwelcome to their doctors. ${ }^{3}$ People in fact guess more than their doctors give them credit for. Patients with cancer, for instance, often have their suspicions from the start, and in hospital clues come to them from many unofficial sources. ${ }^{4}$ At an Edinburgh hospice some patients thought by their doctors to be ignorant of their diagnosis had actually referred themselves for terminal care. ${ }^{5}$ But an open approach gives patients a better chance of making practical and personal adjustments to the likelihood of death and getting the most out of remaining life, besides gaining more explicit support from relatives, doctors, and others.

Nevertheless, telling too much too bluntly, without providing support or follow-up, may cause great misery; and no single approach will be right for everyone. Dr R L Souhami, who introduces students to these difficult skills through seminars in which patients take part, ${ }^{3}$ discussed some of the main needs. Firstly, the doctor who tells his patient the truth must talk to him alone and must appear to have unlimited time. Someone who is frightened will literally fail to understand what is said to him, so further discussions are essential, with plenty of opportunity for questions. Secondly, however grim the prognosis, the doctor should hold out some hope of useful life before death-and remember that statistics of survival are unhelpful to the individual. Thirdly, he must anticipate the patient's anxieties after he leaves hospital with the knowledge of his diagnosis, when minor aches and pains will soon take on a sinister significance. Thus the patient should have carte blanche to talk to the doctor whenever he feels the need.

We must learn to spot the people who particularly need to talk about their problems, or who require special help in the face of death, said Professor Tom Arie, but sometimes we get it painfully wrong. Dr Colin Murray Parkes emphasised the importance of exploring precisely what a patient is afraid of and of giving specific help or reassurance for specific fears.
The main fears he had found in the dying ${ }^{6}$ were separationfrom relatives, home, and job; the plight of dependants; losing control, crying, not dying well; being a burden or a nuisance; weakness and dependence; incontinence; pain (surprisingly, in a minority); confusion; and mutilation. Though clearly many fears are amply justified the doctor should be able to give some help. Mutilation is in the eye of the beholder, and doctors-and others-can reassure by staying close and not avoiding the bedside; distress can be expressed, shared, and worked through - and the patient should have, as it were, permission to cry; and facing the unknown is easier if there are people to trust. Thus doctors and nurses must become parent figures creating a safe place to die in, whether in hospital or at home, and giving support to both patient and relatives.

Faced with dying patients doctors often have no eye for the details of their condition; yet, said Professor Arie, they should look as critically at their problems as at any others, identifying the separate components of their suffering and working out a proper programme of management. For example, pain, breathlessness, difficulty with swallowing, treatable depression, and distress at the humiliations, the mess, and the dependence of terminal illness all call for a specific response. Doctors also tend to forget the commonplace difficulties of illness such as domestic arrangements, and Professor Arie urged that they should ask questions and be more sensitive to the practical problems.

Shakespeare's "Give sorrow words" was quoted at the conference, and a recurring theme was talking and listening. We have become familiar with the concept of total care for the dying developed at St Christopher's and other hospices, emphasising mental, social, and spiritual as well as physical wellbeing ${ }^{4}$; but most people have no contact with a hospice or similar unit and in any case may need help long before the terminal stage of their illness. How can the busy doctor find time for them ? Doctors with a full NHS work load who do try to talk to their patients at length may find themselves under intolerable strain. Outside hospital the general practitioner is the obvious helper, though where the disease and treatment are complicated he may not know all the medical answers. And he also may feel that he has not the time. But time clearly is not the only problem. Necessary detachment can all too easily become a blunting of the sensibility-which may indeed seem a welcome shield against a subject fraught with discomfort. Possibly the chief need is for the doctor simply to relate, with openness, to the patient, having come to terms with his own mortality. Unless he can do this, without an appearance of hurry, his visits may have no impact. Someone illustrated this with the immortal words of A A Milne ${ }^{7}$ : "Said Eeyore ... 'I make it seventeen days come Friday since anyone spoke to me.' ... said Rabbit ... 'I was here myself a week ago.' 'Not conversing,' said Eeyore. 'Not first one and then the other. You said "Hallo" and Flashed Past." "

${ }^{1}$ Hinton J. Talking with people about to die. $B r$ Med $\mathcal{F} 1974$;ii:25-7.

2 Brewin TB. The cancer patient: communication and morale. $\mathrm{Br}$ Med $\mathcal{F}$ 1977 ;ii:1623-7.

${ }^{3}$ Souhami RL. Teaching what to say about cancer. Lancet 1978;ii:935-6.

4 Saunders CM. Appropriate treatment, appropriate death. In: Saunders $\mathrm{CM}$, ed. The management of terminal disease. London: Edward Arnold, 1978:1-9.

${ }^{5}$ Doyle D. The way we live and die. Scotsman 5 February 1980:12.

${ }^{6}$ Parkes CM. Psychological aspects. In: Saunders CM, ed. The management of terminal disease. London: Edward Arnold, 1978:44-64.

7 Milne AA. The House at Pooh Corner, ch 9. London: Methuen Children's Books, 1928. 